\title{
Case Report: Management of Pit Viper Envenoming without Antivenom: A Case Series
}

\author{
Navin Bhatt, ${ }^{1 *}$ Amul Singh, ${ }^{1}$ and Sanjib Kumar Sharma ${ }^{2}$ \\ ${ }^{1}$ Department of Medical Services, Bayalpata Hospital (Nyaya Health Nepal/Possible), Achham, Nepal; ${ }^{2}$ Department of Internal Medicine, B. P. \\ Koirala Institute of Health Sciences, Dharan, Nepal
}

\begin{abstract}
Pit viper envenoming is common in the hilly and the Himalayan regions of Nepal. Antivenom present in Nepal is unlikely to neutralize the venom of these pit vipers, although it has been used often by the healthcare providers in the clinical practice. Here, we report 15 cases of snakebite with a deranged coagulation profile. All patients recovered from envenoming on conservative management and without the administration of antivenom.
\end{abstract}

\section{INTRODUCTION}

Snakebite, with an estimated 20,000 snakebites annually, is a major public health issue in Nepal. ${ }^{1}$ Pit viper envenoming is common in the hilly and the Himalayan region and produces cytotoxic and hemotoxic effects. ${ }^{2}$ The only specific antidote of snakebite envenoming is antivenom. The polyvalent antivenom produced against "big four" in India is imported to Nepal and contains no naturalizing antibodies against pit viper venom. ${ }^{3}$ However, in clinical practice, it is observed that the antivenom is administered to treat pit viper envenoming by healthcare providers. We report 15 cases of pit viper envenoming managed conservatively without administrating antivenom.

\section{CASE REPORT}

In 2019, 15 snakebite patients were seen in the emergency room of Bayalpata Hospital. They presented with swelling, pain, blisters, tingling, and burning sensation of the bitten limb and dizziness (Table 1). The swelling was localized to the bite area in 10 patients, whereas it extended all over the bitten limb in five patients. The fang marks of snakebite were present in all the patients. The patients were hemodynamically stable and had no spontaneous bleeding or neurotoxic manifestation. Laboratory investigation suggested coagulopathy in all the patients. The 20-minute whole blood clotting test (20WBCT) was positive in addition to deranged prothrombin time and international normalized ratio (PT/INR) in all the patients. Renal function tests were normal. Patients were observed closely and managed conservatively. Conservative management included monitoring of vital signs, urine output, laboratory parameters, clinical status, limb immobilization, bed rest, analgesics, and local wound care. Intramuscular injections were avoided. Tetanus toxoid was administered after the normalization of INR values. None of the patients were given antivenom or blood transfusion. The hospital stay was 3-8 days. All the patients recovered from coagulopathy.

\section{DISCUSSION}

Antivenom is the specific antidote for snakebite envenoming. Although monovalent antivenom is the definite antidote

\footnotetext{
${ }^{*}$ Address correspondence to Navin Bhatt, Department of Medical Services, Bayalpata Hospital (Nyaya Health Nepal/Possible), Sanfebagar Municipality-07, Achham 10705, Nepal. E-mail: n.navin.bhatt@ gmail.com
}

that can neutralize the specific snake venoms, it is not available in Nepal. Nepal imports antivenom produced in India against snakes of Indian origin and contains neutralizing antibodies for the venom of common krait (Bungarus caeruleus), common cobra (Naja naja), Russell's viper (Daboia russelii), and saw-scaled viper (Echis carinatus). Krait and cobra cause neurotoxic envenomation and are the major envenoming species in Terai. Envenoming due to Russell's viper is scarce, and saw-scaled vipers are not reported from Nepal. ${ }^{2,4}$

Green pit vipers and mountain pit vipers are widely distributed and frequently encountered venomous snake species in the hills and mountains of Nepal. ${ }^{2}$ Most of the snakebites that had been presented to our hospital emergency belonged to those species of snakes. No antivenom is available to treat pit viper envenoming. There is no evidence that the polyvalent snake antivenoms imported from India neutralized venoms of other species of snakes of Nepal. ${ }^{2,5}$

Most of our patients presented with local symptoms and coagulopathy. The common tests to measure coagulopathy due to hemotoxic snake envenoming are 20WBCT and PT/INR. ${ }^{6,7}$ All our patients had incoagulable blood on 20WBCT, and the PT/INR level was deranged to the undetectable level in eight patients. The patients were kept in observation with regular monitoring until the coagulation profile normalized, and the patients improved clinically. None of the patients received antivenom or blood products. All the patients recovered with no complications, although the hospital stay was longer (average 5 days) for patients with an undetectable INR value at admission.

The positive 20WBCT and undetectable range of PT/INR can be worrisome for the healthcare personnel in the rural settings where the health workers are the mid-level healthcare providers and have to work on their own without any guidance and supervision, and they may feel impelled to use the antivenom that is available even in unrelated species such as pit vipers. This practice of using antivenom has become the part of normal practice in many of the healthcare settings in Nepal, with little reference to whether available antivenom is beneficial. Even the WHO has not tackled this issue sufficiently in its guideline on snakebite envenoming in the Southeast Asia region. The inappropriate use of antivenom exposes patients to a large amount of equine protein that may possibly cause anaphylactic reactions and death. ${ }^{6,8}$ In a recent study by Sharma et al., ${ }^{9}$ of 155 patients, $13(8.4 \%)$ patients developed anaphylaxis attributed to snake antivenom administration that caused fatality in eight patients $(5.61 \%)$. Moreover, it is scarce and costly. ${ }^{8,9}$

Pit viper envenoming may cause painful local swelling to more serious features including venom-induced coagulopathy 
TABLE 1

Clinical features of snakebite patients presenting to the emergency room

\begin{tabular}{|c|c|c|c|c|c|c|c|c|c|}
\hline SN & $\begin{array}{c}\text { Agge } \\
\text { (years) }\end{array}$ & Gender & $\begin{array}{c}\text { Envenoming } \\
\text { snakes* }\end{array}$ & Clinical presentation & 20WBCT & PT/INR & $\begin{array}{l}\text { Renal function test (ref: urea: } 15-45 \\
\mathrm{mg} / \mathrm{dL} \text {, creatinine: } 0.4-1.4 \mathrm{mg} / \mathrm{dL} \text { ) }\end{array}$ & $\begin{array}{l}\text { Hospital stay } \\
\text { (days) }\end{array}$ & Recovery status \\
\hline 1 & 41 & Female & $\begin{array}{l}\text { Green pit } \\
\text { viper }\end{array}$ & $\begin{array}{l}\text { Swelling and pain on } \\
\text { the right ring finger }\end{array}$ & Positive & $35.6 / 2.7$ & Urea: 40 , creatinine: 1.2 & 4 & Recovered \\
\hline 2 & 11 & Female & $\begin{array}{l}\text { Green pit } \\
\text { viper }\end{array}$ & $\begin{array}{l}\text { Pain, swelling of the whole } \\
\text { right leg, and blister } \\
\text { formation on the right ankle }\end{array}$ & Positive & $50 / 3.8$ & Urea: 30 , creatinine: 0.9 & 7 & Recovered \\
\hline 3 & 68 & Female & $\begin{array}{l}\text { Mountain } \\
\text { pit viper }\end{array}$ & $\begin{array}{l}\text { Pain and swelling over the } \\
\text { whole right leg }\end{array}$ & Positive & $38 / 2.9$ & Urea: 42 , creatinine: 1.3 & 5 & Recovered \\
\hline 4 & 24 & Female & $\begin{array}{l}\text { Mountain } \\
\text { pit viper }\end{array}$ & $\begin{array}{l}\text { Pain and swelling over the } \\
\text { left ring finger, and burning } \\
\text { and tingling sensation of } \\
\text { the whole bitten limb }\end{array}$ & Positive & $190.5 / 16.7$ & Urea: 22, creatinine: 1.2 & 4 & Recovered \\
\hline 5 & 18 & Male & $\begin{array}{l}\text { Green pit } \\
\text { viper }\end{array}$ & $\begin{array}{l}\text { Dizziness and minimal swelling } \\
\text { over the bitten area (left thumb) }\end{array}$ & Positive & $160 / 12$ & Urea: 31.3 , creatinine: 1.3 & 6 & Recovered \\
\hline 6 & 27 & Male & $\begin{array}{l}\text { Green pit } \\
\text { viper }\end{array}$ & $\begin{array}{l}\text { Pain and swelling over the } \\
\text { whole right leg }\end{array}$ & Positive & $53 / 4$ & Urea: 26.1 , creatinine: 1.2 & 4 & Recovered \\
\hline 7 & 68 & Female & $\begin{array}{l}\text { Green pit } \\
\text { viper }\end{array}$ & $\begin{array}{l}\text { Pain and swelling over the } \\
\text { whole right leg }\end{array}$ & Positive & $38 / 2.9$ & Urea: 44.1 , creatinine: 1.2 & 5 & Recovered \\
\hline 8 & 52 & Male & $\begin{array}{l}\text { Green pit } \\
\text { viper }\end{array}$ & $\begin{array}{l}\text { Pain and swelling over right } \\
\text { ankle, use of tourniquet just } \\
\text { below the knee, and swelling } \\
\text { present below the tourniquet site }\end{array}$ & Positive & Undetectable & Urea: 29.1, creatinine: 0.7 & 3 & Recovered \\
\hline 9 & 23 & Male & $\begin{array}{l}\text { Green pit } \\
\text { viper }\end{array}$ & $\begin{array}{l}\text { Swelling over the right ankle } \\
\text { region, and tingling and burning } \\
\text { sensation over the bitten area }\end{array}$ & Positive & Undetectable & Urea: 23 , creatinine: 0.6 & 3 & Recovered \\
\hline 10 & 35 & Female & $\begin{array}{l}\text { Green pit } \\
\text { viper }\end{array}$ & $\begin{array}{l}\text { Snakebite on the right ring } \\
\text { finger and minimal swelling } \\
\text { over the bitten finger }\end{array}$ & Positive & Undetectable & Urea: 24.8 , creatinine: 0.7 & 3 & Recovered \\
\hline 11 & 77 & Female & $\begin{array}{l}\text { Green pit } \\
\text { viper }\end{array}$ & $\begin{array}{l}\text { Pain and swelling on the right } \\
\text { ankle joint }\end{array}$ & Positive & Undetectable & Urea: 44 , creatinine: 1.3 & 8 & Recovered \\
\hline 12 & 15 & Female & $\begin{array}{l}\text { Green pit } \\
\text { viper }\end{array}$ & $\begin{array}{l}\text { Pain and swelling on the whole } \\
\text { right leg }\end{array}$ & Positive & Undetectable & Urea: 18.5 , creatinine: 0.5 & 7 & Recovered \\
\hline 13 & 18 & Female & $\begin{array}{l}\text { Green pit } \\
\text { viper }\end{array}$ & $\begin{array}{l}\text { Pain and swelling on the right } \\
\text { ankle joint }\end{array}$ & Positive & Undetectable & Urea: 22.2 , creatinine: 0.8 & 4 & Recovered \\
\hline 14 & 27 & Female & $\begin{array}{l}\text { Green pit } \\
\text { viper }\end{array}$ & $\begin{array}{l}\text { Snakebite on the left ring finger, } \\
\text { pain and burning sensation } \\
\text { over the whole bitten limb, } \\
\text { and minimal swelling over } \\
\text { the bitten area }\end{array}$ & Positive & Undetectable & Urea: 42 , creatinine: 1.0 & 5 & Recovered \\
\hline 15 & 33 & Female & $\begin{array}{l}\text { Mountain } \\
\text { pit viper }\end{array}$ & $\begin{array}{l}\text { Pain and burning sensation } \\
\text { over the bitten left foot } \\
\text { and minimal swelling over } \\
\text { the bitten area }\end{array}$ & Positive & Undetectable & Urea: 32, creatinine: 1.1 & 6 & Recovered \\
\hline
\end{tabular}

and spontaneous bleeding as recorded recently from eastern Nepal (R. Ruiz de Castañeda et al., unpublished observations). However, polyvalent antivenom (imported to Nepal from India) is not indicated in pit viper envenoming and should be managed conservatively in the hospital.

Coagulopathy is a common manifestation of pit viper envenoming in Nepal and can be managed conservatively without the administration of antivenom currently available in Nepal. The inappropriate use of antivenom wastes the scarce antivenom and has financial implications and also exposes patients to the adverse effect of antivenom, including fatal reactions.

Although all our patients were successfully treated with conservative management without complications, we may not have seen the full spectrum of pit viper envenoming in patients presenting to our hospital. Thus, although we did not identify a clear need for specific antivenom for pit viper envenoming, it would not be prudent to conclude from this sample of patients that there is no need for specific antivenom.

Received January 14, 2020. Accepted for publication February 25, 2020.

Published online March 30, 2020.

Acknowledgments: We would like to thank the electronic health record (EHR) and IT team of Nyaya Health Nepal/Possible for technically helping us with the acquisition of needful data and patient records. The American Society of Tropical Medicine and Hygiene (ASTMH) assisted with publication expenses.

Authors' addresses: Navin Bhatt and Amul Singh, Department of Medical Services, Bayalpata Hospital (Nyaya Health Nepal/Possible), Achham, Nepal, E-mails: n.navin.bhatt@gmail.com and amulsingh09@ gmail.com. Sanjib Kumar Sharma, Department of Internal Medicine, B. P. Koirala Institute of Health Sciences, Dharan, Nepal, E-mail: drsanjib@ yahoo.com. 


\section{REFERENCES}

1. Sharma SK, Bovier P, Jha N, Alirol E, Loutan L, Chappuis F, 2013. Effectiveness of rapid transport of victims and community health education on snake bite fatalities in rural Nepal. $A m \mathrm{~J}$ Trop Med Hyg 89: 145-150.

2. Sharma SK, Pandey DP, Shah KB, Tillack F, Chappuis F, Thapa CL, Alirol E, Kuch U, 2013. Venomous Snakes of Nepal. Dharan, Nepal: B.P. Koirala Institute of Health Sciences, 1-76.

3. Shrestha BR, Pandey DP, Acharya KP, Thapa-Magar C, Mohamed F, Isbister GK, 2017. Effective, polyvalent, affordable antivenom needed to treat snakebite in Nepal. Bull World Health Organ 95: 718-719.

4. Bartaula B, Shah B, Bhurtel N, Sharma SK, 2018. Acute kidney injury due to Russell's viper envenomation: first documented case in Nepal. J Adv Intern Med 7: 45-46.
5. Pandey DP, Ghimire A, Shrestha BR, 2019. Retrospective documentation of a confirmed white-lipped green pit viper (Trimeresurus albolabris Gray, 1842) bite in the South-central hills of Nepal. Wilderness Environ Med 30: 79-85.

6. Maduwage K, Isbister GK, 2014. Current treatment for venominduced consumption coagulopathy resulting from snakebite. PLoS Negl Trop Dis 8: e3220.

7. Pongpit J, Limpawittayakul P, Juntiang J, Akkawat B, Rojnuckarin $P, 2012$. The role of prothrombin time (PT) in evaluating green pit viper (Cryptelytrops sp) bitten patients. Trans $R$ Soc Trop Med Hyg 106: 415-418.

8. Isbister GK, Duffull SB, Brown SGA, 2009. Failure of antivenom to improve recovery in Australian snakebite coagulopathy. QJM 102: 563-568.

9. Sharma SK et al., 2019. Acute severe anaphylaxis in Nepali patients with neurotoxic snakebite envenoming treated with the VINS polyvalent antivenom. J Trop Med 2019: 2689171. 